\title{
The limits of discourse: masculinity as vulnerability
}

\author{
Lindsay Clowes
}

\begin{abstract}
For many, gender equity - being fair to women and men - is a zero sum game in which men should be willing to give up their privileges for the creation of a more equitable and just society. The idea that men might benefit from gender equity seems, for many, unthinkable. This was brought home a few years ago in a gender studies test, when students answering a question on what men might gain from gender equality explained instead how women would benefit. In this Perspective I reflect on the ways in which popular discourses around gender may inadvertently undermine movement towards gender and social justice. Dismissing my students' answers as the result of poor teaching or learning misses a key point: It seems to be extraordinarily difficult for most people to recognise how gender creates masculine vulnerabilities or how gender equity could benefit men. I suggest that if we are to improve women's lives through the reduction of violence, feminist teachers and activists need to think creatively about how to help men and boys understand that performances of masculinity deeply compromise their own lives.
\end{abstract}

Gender equity - being fair to women and men - means recognising, acknowledging and, most importantly, addressing the myriad ways in which women are socially, economically and politically disadvantaged in daily life. At the same time it also means acknowledging the ways in which men's gender makes them vulnerable to harm, and the ways in which simply making women's lives more like men's would not see women's lives improve. Gender equity leads to gender equality, whereby access to opportunities, benefits and resources is neither linked to nor dependent upon a person's gender. But for many, if not most South Africans, gender equity appears to be a zero sum game in which only women stand to benefit. The idea that men might have anything to gain from gender equity or gender equality appears, for many, quite literally unthinkable. This was driven home last year when I set my students a test question asking about the potential benefits of gender equity for men. When all bar two (of the 60 odd students who selected this question) were silent about any possibility of gender equity having anything to offer men (writing instead of ways women would benefit) I was somewhat taken aback. One of the 12 lectures, and one of the small group tutorials had focused directly on the question of why gender inequalities should matter to men and the issue had also been touched on in other lectures. In classes we had drawn, for example, on the insightful analysis by Kopano Ratele to think about the ways in 
which gender does compromise the well-being of South African men. Along with masculinities theorising from Raewynn Connell and Michael Kimmel, students had also been offered a variety of local newspaper clippings that focused on practices of masculinity that were harmful to men. In a society where 'size counts' one of these clippings had explored the 'obsession to build muscle' and the increasing pressure on South African men to look good through harmful practices of self-styling. Reporting on bodybuilding supplements including but not limited to steroids - that cost as much as R25 000 a month, the article foregrounded the cost to men's health, their libido, and their relationships ('Bigorexia: when being big is never enough', Sunday Times: Lifestyle, 21 March 2010). Entitled "Why I wanted to kill my family", another clipping saw Dawood Schloss outline the "quiet desperation" of the struggle to provide for four children against a context in which "we refuse to let our neighbours or even our own families know the situation we find ourselves in" (Sunday Argus, 5 November 2006). Yet another clipping pointed to the increased risk of premature death facing young men (P Reaney, 'Risky lifestyle of young men leads to higher death rate', Cape Times, 28 July 2006), another to understandings in the police force that accessing counselling services compromised a man's chances of promotion, as well as others that reflected on policemen who killed their families (A Hartley, Three children shot: policeman father to face murder charges', Cape Times, 31 July 2006; Y Groenewald, 'Killer cops', Mail \& Guardian, 7-12 April 2006).

Despite what I had thought to be fairly substantial exposure to the idea that the ubiquity of men's violence towards themselves and others might be linked to men's attempts to live up to normative expectations of patriarchal masculinity, my students - both male and female - seemed to have enormous difficulty in saying anything at all about what gender equity might offer men. In sharp contrast, their writing about women was fluent and articulate. They drew attention to the high levels of violence that characterise gendered relationships in South Africa and the ways in which South African women can be characterised - as Pumla Gqola (2007) has observed - as 'under siege'. Many observed that the sexual and physical assaults that see the bodies of women and girls injured, maimed and even killed, and that have seen South Africa designated as the global rape capital, are complemented by the psychic and emotional violence of gender normativity. Several made some mention of the physical, emotional and psychic violence that pervades the entire life of every woman, and commented on the ways in which material violence accumulates to compromise women's opportunities on virtually every marker of well-being.

My students were equally articulate about ways in which the education of girls and women remains compromised by schooling that continues to reflect the gender normative hierarchies of the broader societal context. They were eloquent in their critique of normative expectations that girls and women will take on the bulk of the unpaid household maintenance and nurturing work and how this further compromises a woman's lifetime earning potential. Many noted that South African women continue to earn substantially less than men, 
and remain far less likely to occupy positions of authority and seniority in the workplace such that even after they have reached pensionable age women continue to have lower levels of well-being in relation to men. A few noted that gendered access to economic resources further impacts on levels of nutrition, quality of housing and sanitation as well as access to health services, effectively shaping overall standards of living for women and the children who rely on them.

Almost everything my students wrote in a question about how men might benefit from gender equity foregrounded women and women's subordination and marginalisation. In considering this I was reminded of the point made by Signe Arnfred, writing about gender and development, that women may have learned a discourse of disempowerment that precludes seeing ways in which they are powerful. "You would know", she states:

"if women had been in contact with gender-and-development efforts [because] they would have acquired a language of women's subordination, having learned to see themselves as powerless and oppressed" (Arnfred, 2001: 81).

I wondered, given the ways their writing so strongly foregrounded how gender equity would improve women's lives, about the extent to which my students, both male and female, might also have learned a language of women's subordination. It seemed that, in their minds, and presumably in the popular imagination of the communities from whence they came, a more just and democratic society had everything to offer women and little or nothing to offer men.

At the same time, while their eloquence with regard to women was marked, more striking still was my students silence about men. In reflecting on this I was reminded of the observation made by American feminist bell hooks - that it is not permitted to speak openly and honestly about men (hooks, 2004). Tammy Shefer has noted that that South African researchers have tended to ask questions about the ways in which patriarchal privileges work to disempower women, deploying analyses that construct men as privileged oppressors, as perpetrators rather than victims of violence (Shefer et al, 2007). These understandings are further strengthened by media reports that consistently and uncritically reproduce images of men as aggressive and violent, and women as vulnerable and passive (Buthelezi, 2007; Sanger, 2007; Sanger and Hadland, 2008). Such meanings seem to have strongly shaped the writing of my students. In erasing the possibility that men might have anything to gain from gender equity other than the loss of their privileges, my students' answers tended to position men as 'the problem'. Such discourses, as Shefer et al (2007) have noted, are widespread, and serve, as hooks has emphasised, to position men rather than particular versions of masculinity as the "enemy" (hooks, 2004: 39). That there is such limited discursive space (either inside or outside the classroom) from which to consider the possibility that gender inequalities are harmful to men (or that conversely gender equity has anything to offer men) is deeply problematic. 


\section{'Ungendered' men}

In suggesting that men have a great deal to gain from gender equity I am not suggesting, as Marilyn Frye puts it, "that the oppressors are oppressed by their oppressing" (2003: 13). I am, however, making a related point, that popular discourse presents us all - and men in particular - with very limited possibilities for acknowledging and understanding the price men pay for the privileges claimed in the name of hetero-patriarchal masculinity. This, I suggest below, is a problem for men as well as for women. Evidence, admittedly anecdotal, from class debates and discussions in a range of undergraduate classes suggest that my students and many, if not most men, understand masculinity as presocial. They simply don't see themselves as gendered. In employing enquiry-based and authentic learning approaches (Herrington and Herrington, 2006) in my gender studies courses, for example, I require students to conduct interviews and to report back on these interviews in class where we have a discussion led by four or five students. Two years ago students asked men questions about how clothes signalled gender. Many students reported that men were either unable to answer the question or insisted that masculinity was not signalled by clothes. The following year second year students were required to interview an elderly person of the same sex and to compare and contrast ways in which normative practices of gender changed or stayed the same across generations. Again many students reported that men found this question difficult to answer, with numerous male informants insisting that (unlike their sisters) gender had played no role at all in their childhoods. Kimmel (2003: 1) has employed a metaphor of a strong wind to describe how American men fail to recognise that they are gendered. "You do not feel the wind", he says, "it feels you". "You do not feel how it pushes you along; you feel only the effortlessness of your movements. You feel like you could go on forever." It is only when one turns to face the wind, and movement that had come so easily a moment before becomes a struggle, that one recognises its power. The invisibility of the wind, to continue Kimmel's metaphor, no doubt helps explain why events foregrounding masculinities and gender, events aimed at encouraging men to be a part of challenging gender inequalities, attract so few men (K Ratele, 'Feminist men have more fun', Times Live, 21 September 2012).

Yet while my students might be mute about the advantages of gender equity for men, they are still able to draw attention to men's behaviour that is harmful to themselves. They report, for instance, that cigarette smoking - and its associated health hazards - is a primarily masculine practice. Likewise, excessive alcohol consumption is commonly understood (at least by my students) as separating the men from the boys. One class drew my attention, for instance, to the pulling of the South African Breweries advertisement for Carling Black Label with the pay-off line "Groot man of laaitie" (big man or little boy) that juxtaposed a $750 \mathrm{ml}$ bottle against a pint bottle. Sonke Gender Justice complained that the advertisement "promote[d] excessive drinking" by "play[ing] around the issue of what it means to be a man", and that the idea that " $n$ groot man vra vir ' $n$ hele $750 \mathrm{ml}$ bottle" (a big man asks for the full bottle) was both harmful and inappropriate given the levels of alcohol abuse and in the light of the connection between violence and alcohol abuse (Bodibe, 2010). Yet even though students are able to draw attention to some of the ways in which popular culture encourages men to engage in risky and harmful 
behaviours, it seems as if these behaviours are not understood as performances of gender. The possibility that gender equity might benefit men is thus obscured by the opacity of the relationship between masculinity and gender and the sheer unthinkability of the idea that masculinity is a performance of gender, that drinking a bottle of beer might itself be a performance of gender.

\section{Privilege and patriarchy: the price men pay}

Research, as Jeff Hearn (2007: 17) has noted, is making it increasingly clear that "[p]atriarchy, or patriarchies, is not only bad news for women, but also in different ways for many boys and men". "The first act of violence patriarchy demands of males" says bell hooks, "is not violence towards women". For hooks, the first act of violence patriarchy requires from men is that "they engage in acts of psychic self-mutilation" (hooks, 2004: 66). In South Africa dominant masculinities structured around race, sexuality and class have been unsettled by the sweeping constitutional changes that have enshrined gender equality as a fundamental feature of post-apartheid South Africa. The legacies and remnants of these institutionalised patriarchies have combined with global economic change to leave many men unable to live up to their own expectations of themselves (Ratele, 2008; Walker, 2005; Motsemme, 2002; Epstein, 1998). High rates of poverty and unemployment alongside constitutional imperatives of gender equity and affirmative action mean, for example, that masculinities built around class, access to resources and the role of the economic provider are increasingly stressed (Walker, 2005; Silberschmidt, 2004; Ratele, 2002). These stresses and strains find expression as gendered practices that threaten other men, women and children as well as the self (Hearn, 2007; Lazarus et al, 2008; Clowes et al, 2010).

A range of studies have also begun to explore how doing masculinity intersects with other salient subjectivities to make men vulnerable to harm, with evidence increasingly suggesting that it is young men, for example, who are the predominant victims of male violence (Altbeker, 2006; Krug et al, 2002; Norman et al, 2007; Pelser, 2008). Kopano Ratele (2006: 279) writes that it is South African men, rather than South African women who die from "man-made" causes, while Prinsloo (2007) notes that there are approximately four male victims of nonnatural deaths for every female victim. In South Africa, the National Injury Mortality Surveillance System (NIMSS) suggests that men are about six times more likely to be victims of homicide than women (Donson, 2008), while the rate of interpersonal violence among and between young men is nine times higher than the corresponding global average (Norman et al, 2007). But, in the popular understanding, at least, such knowledge doesn't seem to connect with discourses around gender equity, let alone masculinity as a performance of gender.

While risky behaviours built around competition and authoritarianism seem to be relatively universal markers of patriarchal masculinity, subject locations structured around race, class, age, ethnicity and sexuality and other salient positionalities mean that different groups of men are at risk in different kinds of ways in contemporary South Africa. It is their gender, for example, that 
positions white middle-class men in their 50s with the highest risk of dying from stress related diseases such as strokes and heart attacks, just as it is gender that helps explain why people who are ill might not seek medical attention until it is too late. It is, primarily, their gender that makes young men vulnerable to the lure of toxic body building drugs such as steroids, and gender that explains who is likely to be involved in alcohol related accidents and violence. While race, class and age might be important, it is gender that is key to explaining who risks life and limb 'train-surfing' in contemporary South Africa (Sedite et al, 2010). Similarly gender is central to any explanation of who is most likely to engage in sex with multiple partners, who is most likely to engage in unprotected sex (Hunter, 2005; Campbell, 2001) and who might be stigmatised for aspiring to a monogamous sexual relationship (Lindegger and Maxwell, 2007). Gender is as important as race, class and age in explaining who is likely to die at school and who is likely to die between Friday night and Monday morning in some areas of the Cape Flats. Gender is equally as central in explaining who died at Marikana recently - every single one of those who died was a man as much as they were black and they were workers.

Somehow though, despite all this evidence, the idea that men might have much, if anything to gain, through gender equity acquires little or no traction in popular discourses. So what is it that men and boys might gain from gender equity? The simple answer is their health, their lives and their wellbeing. As Ira Horowitz observed way back in 1997:

"When the lives men lead are examined closely ... it becomes obvious that by trying to follow the roles proscribed for us by our socialisation, we suffer serious physical, psychological and emotional harm. As a result, we live very pressured lives and, on average, die younger than women; we spend much of our lives feeling like failures and, because we cannot express those feelings, we often numb them out with alcohol and drugs"(Horowitz, 1997: 75).

bell hooks succinctly sums this up with the observation that "[p]atriarchy demands of men that they become and remain emotional cripples" (hooks, 2004: 27). All men, insists hooks, "are imprisoned by a system that undermines their mental health" (hooks, 2004: 30).

The point I am making is that the reduced physical, psychic and emotional violence that is central to gender equity would mean substantial benefits for men's physical well-being as well as for their psychic and emotional health. It would mean that more young men on the Cape Flats would be alive to celebrate their $2 \mathrm{O}^{\text {th }}$ birthdays and that fewer elite men would die of stress-related diseases before they reach pensionable age. Apart from emptying the prisons, where, in 2008, men out-numbered women in a ratio of about 45:1 (Department of Correctional Services, nd: 10), the reduction in violence inherent in gender equity would also have positive spin-offs in terms of men's relationships with family, friends and colleagues, there by building stronger support networks for times of hardship and stress - particularly relevant today given the increased 
levels of unemployment in the wake of global recession. Gender equity - in the form of more democratic rather than authoritarian and more patriarchal relationships - would further strengthen these support networks. The development of more egalitarian relationships through more equitable sharing of the economic, emotional and physical burdens of paid and unpaid work as well as more equal contributions to unpaid work in the form of household maintenance and child raising could also contribute to more realistic (and gender equitable) expectations of self by men. A different - and more gender equitable - understanding of the supposed 'invulnerabilities' of the masculine body might see a reduction in substance abuse and risky behaviours, alongside an increased willingness to make use of the healthcare system at earlier stages of ill health - with positive outcomes for men's health in both the short and the longer term. A shift away from patriarchal authoritarianism towards the more egalitarian versions of masculinity required by gender equity might allow policemen, soldiers and even civilian men enhanced opportunities to obtain counselling (and better mental health) without the stigma so often attached to requests for help from men, and without compromising their prospects for career advancement. Gender equity, in short, has substantial and extensive gains to offer men of all ages, classes and ethnicities.

\section{Lessons for teaching and the need for counter discourses}

My students' answers imply that the historical focus on gender equity as offering the potential to improve women's lives has inadvertently contributed to a dominant discourse in which gender equity has nothing good to offer men. The paradox of course is that dominant discourses that offer men nothing but the loss of privilege surely incentivise men to evade or resist movement towards gender equity, to continue the practices that impact negatively on themselves as well as the rest of us. And yet the physically, emotionally and psychically violent practices that lie at the very heart of women's subordination compromise men's lives even more than they do women's. The general invisibility of the enormously high costs of masculine privilege for men need to be better understood and to be challenged. This poses a dilemma for contemporary feminist teaching and activism. On the one hand care needs to be taken to ensure that resources are not diverted from work aimed at improving women's lives. On the other, it is only through a focus on men and masculinity, through foregrounding masculinity as a performance of gender, rather than nature, that men and boys are likely to begin to understand that they too are gendered, that their gender exposes them to avoidable harm and profoundly threatens their well-being. That masculinity is social practice rather than biological imperative is evident from the work of people like Tina Sideris (2005) in raising men's consciousness of the need to change, and men's organisation for gender equality, such as Sonke Gender Justice. Their work demonstrates that men can do masculinity differently, and that men are able to learn to understand and experience change in their gendered behaviour as enormously beneficial to themselves. 
In their inability to speak about masculi nity as a man-made creation that is deeply harmful to men as well as women, my students have signalled a challenge for the teaching and learning taking place in my classroom. Rather than dismissing my students'answers to the test I set as the result of poor teaching or poor learning, their answers are valuable precisely because they highlight how the vulnerabilities produced by contemporary masculinities (and concomitant benefits of gender equity for men) are so firmly outside the limits of contemporary discourse. If we are to contribute to the development of graduates who are critical citizens, equipped with the tools and motivation to work towards gender equity and social justice, we need to challenge understandings that conflate gender with women or that locate oppression as a women's problem, we need to problematise discourses that dismiss or marginalise complexity.

I aim to respond to the challenge set down by my students through teaching that draws more directly on the subject locations and discursive spaces inhabited by my students and to focus more carefully on positions of privilege and how these are mediated in their own lives by race, sexuality, age, ethnicity, class and so on. Students themselves can be asked to reflect on the obstacles to understanding masculinity as a performance of gender, or be asked to contemplate why it is so difficult to imagine ways in which men might benefit from gender equity. A key issue would be to explore student understandings of challenges to the hegemonic discourses outlined above and to consider how to develop a counter discourse, one that foregrounds men's agency in challenging patriarchal masculinity for their own sakes. Taking student's struggles with these questions seriously will, I hope, help develop insights that enrich my teaching, thereby contributing to the production of graduates who are critical and engaged citizens committed to the social, political and economic transformation inherent in gender equity, a transformation that would benefit both men and women. 


\section{References}

Altbeker A (2006) 'Why is crime in South Africa so uniquely violent?', Harold Wolpe Memorial Trust's $55^{\text {th }}$ Open Dialogue, 30 November 2006, Cape Town, Paper and transcript of discussion.

Arnfred S (2002) 'Questions of power: women's movements, feminist theory and development aid', in Discussing Women's Empowerment: Theory and Practice, Sida Studies No 3, Goteborg: Sida.

Bodibe K (2010) 'SAB forced to pull beer ad', available at: http://www.healthe.org.za/news/article.php? uid=20032834 site accessed 19 September 2012.

Buthelezi T (2007) 'The intersection of gender and class in Ilanga and Isolezwe news coverage of rape', in Agenda, 74, 125-132.

Campbell C (2001) 'Going underground and going after women: masculinity and HIV transmission amongst black workers on the gold mines' in R Morrell (ed) Changing Men in Southern Africa, Pietermaritzburg: University of Natal Press.

Clowes L, Lazarus S \& Ratele K (2010) 'Risk and protective factors to male interpersonal violence: Views of some male university students', in African Safety Promotion: A Journal of Injury and Violence Prevention, 8, 1, 1-19.

Department of Correctional Services (nd) National Offender Population Profile in the Department of Correctional Services Using Statistical Data up to $30^{\text {th }}$ June 2008, Republic of South Africa, available at: http://www.info.gov.za/view/DownloadFileAction?id= site accessed 20 September 2012. Donson H (ed) (2008) A Profile of Fatal Injuries in South Africa 2007, Tygerberg: Medical Research Council - University of South Africa, Crime Violence and Injury Lead programme.

Epstein D (1998) 'Marked men: Whiteness and masculinity', in Agenda, 37, 49-59. Frye M (2003) ‘Oppression'in M Kimmel and A Ferber (eds) Privilege: A Reader, Boulder: Westview Press.

Government of South Africa (1996) The South African Schools Act, No 84.

Gqola P (2007) 'How the "cult of femininity" and violent masculinities support endemic gender based violence in contemporary South Africa', in African Identities, 5, 1, 111-124.

Hearn J (2007) 'The problems boys and men create, the problems boys and men experience' in T Shefer, K Ratele, A Strebel, N J Shabalala \& R Buikema (eds) From Boys to Men: Social Constructions of Masculinity in Contemporary Society, Landsdowne: UCT Press.

Herrington T \& Herrington J (2006) Authentic Learning Environments in Higher Education, available at: http://www.igi-global.com/book/authenticlearning-environments-higher-education/93 site accessed on 30 October 2012.

hooks b (2004) The Will to Change: Men, Masculinity and Love, New York: Atria Books.

Horowitz I (1997) 'Sexism hurts us all', in Agenda, 33, 75-80.

Hunter M (2005) 'Cultural politics and masculinities: Multiple partners in historical perspective in KwaZulu-Natal', in Culture, Health \& Sexuality, 7, 4, 389-403.

Kimmel M \& Ferber A (eds) (2003) Privilege: A Reader, Boulder: Westview Press.

\section{https://repository.uwc.ac.za/}


Krug E, Dahlberg L L, Mercy J A, Zwi A B \& Lozano R (eds) (2002) World Report on Violence and Health, Geneva: World Health Organisation.

Lazarus S, Tonsing S, Ratele K \& van Niekerk A (2008) An Exploratory Study into the Risk and Protective Factors to Male Interpersonal Violence, Tygerberg: Medical Research Council.

Lindeggar G \& Maxwell J (2007) Teenage masculinity: the double bind of conformity to hegemonic standards', in T Shefer, K Ratele, A Strebel, NJ Shabalala \& R Buikema (eds) From Boys to Men: Social Constructions of Masculinity in Contemporary Society, Landsdowne: UCT Press.

Motsemme N (2002) 'Gendered experiences of black-ness in post-apartheid South

Africa', paper presented at the $8^{\text {th }}$ International Interdisciplinary Congress on Women, Women's World, Makerere University, Kampala, Uganda.

Norman R, Matzopoulos R, Groenewald P \& Bradshaw D (2007) The high rate of injuries in South Africa', in Bulletin of the World Health Organisation, 85, 9, 695-701.

Pelser E (2008) 'Learning to be lost: Youth crime in South Africa', Discussion paper for the HSRC youth policy initiative, Reserve Bank, Pretoria, Cape Town: Centre for Justice and Crime Prevention.

Prinsloo M (ed.) (2007) The National Injury Mortality Surveillance System (7t t: http://www.sahealthinfo.org/violence/national2005.pdf, site accessed July 5 2010.

Ratele K (2002) 'Contradictions in constructions of African masculinity', News from the Nordic Afrika Institute, available at:

http://www.arscr.org/features/issueso05.htm, site accessed 23 July 2010.

Ratele K (2006) 'Ruling masculinity and sexuality', in Feminist Africa, 6, 48-64. Ratele K (2008) 'Masculinity and mortality in South Africa', in African Safety Promotion: A Journal of Injury and Violence Prevention, 6, 2, 21-35.

Ratele K (2012) 'Feminist men have more fun', available at:

http://www.timeslive.co.za/ilive/ 2012/o9/12/feminist-men-have-moresexual-fun-

ilive site accessed 21 September 2012.

Shefer T, Ratele K, Strebel A, Shabalala NJ \& Buikema R (eds) (2007) From Boys to Men: Social Constructions of Masculinity in Contemporary Society, Landsdowne: UCT Press.

Sanger N (2007) 'Scripts of Western heteronormativity: South African lifestyle' magazines and (hetero) socialisation', in Sexuality in Africa, 4, 2, 7-9.

Sanger N \& Hadfield A (2008) 'Challenging patriarchal scripts? A gender analysis of South Africa's community print media', in Agenda, 77, 4-17.

Sedite D, Bowman B \& Clowes L (2010) 'Perceptions of staffriding in post-apartheid South Africa: the lethal thrill of speed or masculine performance of a painful past', in Journal of Psychology in Africa, Special Edition on The Social Construction of Masculinities in Africa, 20, 4, 581-590.

Sideris T (2005) "'You have to change and you don't know how!": Contesting what it means to be a man in a rural area of South Africa' in G Reid and L Walker (eds) Men Behaving Differently: South African Men Since 1994, Double Storey Books: Cape Town. 
Silbersmidt M (2004) 'Masculinities, sexuality and socio-economic change in rural and urban East Africa' in S Arnfred (ed) Re-thinking Sexualities in Africa, Sweden: Almqvist \& Wiksell Tryckeri AB.

Walker L (2005) 'Negotiating the boundaries of masculinity in post-apartheid South Africa' in G Reid \& L Walker (eds) Men Behaving Differently: South African Men Since 1994, Double Storey Books: Cape Town. 